\title{
Oncologic Outcome and Predictor of Local Recurrence in Patients with Glottic Cancer Treated with Transoral Laser Microsurgery
}

\author{
Sun Woo Kim, Hye Soo Kim, Woo Joo Nam, Sang Hyuk Lee ${ }^{\mathbb{D}}$, and Sung Min Jin \\ Department of Otorhinolaryngology-Head and Neck Surgery, Kangbuk Samsung Hospital, \\ Sungkyunkwan University School of Medicine, Seoul, Korea
}

\author{
경구강 레이저 수술을 시행한 성문암 환자의 치료 결과 및 국소 재발의 예측 인자 \\ 김선우 · 김혜수 · 남우주 · 이상혁 · 진성민 \\ 성균관대학교 의과대학 강북삼성병원 이비인후과학교실
}

\footnotetext{
Received April 7, 2020

Revised May 22, 2020

Accepted June 9, 2020

Address for correspondence

Sang Hyuk Lee, MD, PhD

Department of Otorhinolaryngology-

Head and Neck Surgery,

Kangbuk Samsung Hospital,

Sungkyunkwan University

School of Medicine,

29 Saemunan-ro, Jongno-gu,

Seoul 03181, Korea

Tel +82-2-2001-2269

Fax +82-2-2001-2273

E-mail entlsh@hanmail.net
}

Background and Objectives Transoral laser microsurgery (TLM) is minimally invasive and has become the standard approach for early and intermediate stage laryngeal cancers. Many studies show that the oncologic results of TLM are equivalent to those obtained by conventional conservative surgery and radiotherapy (RT). The purpose of this study were to analyze the treatment outcome and predictors of local recurrence in glottic cancer patients who underwent TLM. Subjects and Method Sixty-seven patients who received TLM for glottis cancer between 2008 and 2019 were analyzed retrospectively. Patients were predominantly male $(98.5 \%)$, with a median age of 64.3 years (range 45 to 87 years). There were 35 cases of T1 (52.2\%), 15 cases of T2 $(22.3 \%)$, and 17 cases of T3 $(25.3 \%)$ in the primary tumor stage. There were no patients with lymph node metastasis (cN0). When classified into types, there were 2 cases of type I ( $3 \%)$, 15 cases of type II (22.3\%), 34 cases of type III (50.7\%), 4 cases of type IV (5.9\%), 12 cases of type V (17.9\%). The local control rate and overall survival rate were calculated with KaplanMeier curve analysis. Additionally, multivariate analysis of factors associated with local recurrence used Cox proportional-hazards model.

Results TLM alone was performed in 54 patients $(80.5 \%)$ whereas 13 patients $(19.5 \%)$ underwent TLM followed by adjuvant RT. The 5-year local control rate and 5-year overall survival rate were $81.9 \%$ and $93.3 \%$, respectively. In the Univariate analysis, the significant factors of local recurrence were difficult laryngeal exposure [odds ratio $(\mathrm{OR})=22.8,95 \%$ confidence inter$\operatorname{val}(\mathrm{CI})=1.7-297.4, p$-value $=0.03]$, anterior commissure invasion $(\mathrm{OR}=17.2,95 \% \mathrm{CI}=1.9-154.7$, $p$-value $=0.004$, positive lymphovascular invasion $(\mathrm{OR}=18.0,95 \% \mathrm{CI}=2.9-109.8, p$-value $=0.003)$ and positive resection margin $(\mathrm{OR}=9.5,95 \% \mathrm{CI}=1.6-55.6, p$-value $=0.011)$. In the multivariate analysis, the independent factors of local recurrence were anterior commissure invasion [hazard ratio $(\mathrm{HR})=18.4,95 \% \mathrm{CI}=1.98-170.99, p$-value $=0.010]$ and lymphovascular invasion $(\mathrm{HR}=7.5$, $95 \% \mathrm{CI}=1.49-38.15, p$-value $=0.015)$. No major or lethal complications were observed.

Conclusion TLM is a reliable modality to treat early and select cases of moderately advanced glottic cancer. Our study found that independent factors of local recurrence included anterior commissure invasion, and lymphovascular invasion. These findings may be useful to follow-up glottic cancer patients after TLM.

Korean J Otorhinolaryngol-Head Neck Surg 2020;63(9):415-21

Key Words Glottis · Laryngeal cancer · Microsurgery · Neoplasm recurrence · Survival rate.

This is an Open Access article distributed under the terms of the Creative Commons Attribution Non-Commercial License (https://creativecommons.org/licenses/by-nc/4.0) which permits unrestricted non-commercial use, distribution, and reproduction in any medium, provided the original work is properly cited. 


\section{서 론}

후두암은 두경부 영역에서 갑상선암 다음으로 발생 빈도가 높으며 전체 악성 종양의 약 2 5\%를 차지한다. 성문암과 성 문상부암이 후두암의 대부분을 차지하며 미국에서는 후두암 중 성문암이 $60 \%$, 성문상부암이 $30 \%$ 정도 차지하고 있다고 보고되고 있다. 성문암은 위쪽으로 성대의 상면을 지나는 수평면까지, 아래쪽으로 성대의 자유연에서 $1 \mathrm{~cm}$ 까지를 말 하며 흡연과 음주가 주요 위험인자로 알려져 있으며 대부분 편평세포암종이다. 성대에서 발생한 암은 대개 분화도가 좋은 암으로, 진행 속도가 느리며 성문상부와 하부에는 림프관이 풍부하게 분포되어 경부 전이율이 높으나, 성문부에는 심부 림프관이 거의 분포하지 않아 경부 전이율이 $2 \sim 5 \%$ 이하로 낮은 것이 특징이다. 또한, 비교적 조기에 애성 등의 증상이 발생하여 발견이 용이하여 예후가 양호한 것으로 알려져 있 다. 성문암의 치료에서 후두의 생리적 기능을 보존하며 삶의 질을 유지하는 것이 질병의 완치와 함께 중요하게 여겨지고 있다.

경구강 레이저 성대 절제술은 1972년 Strong과 Jako가가 후 두 내시경하에서 $\mathrm{CO} 2$ 레이저를 처음으로 도입하였으며, 현재 까지 조기 혹은 일부 진행된 성문암의 치료로 방사선 치료, 후두 부분 절제술, 경구강 레이저 수술 등의 방법이 사용되고 있다. 방법 간의 치료 성적율은 비슷하나 각기의 치료 방법 모두 장단점을 가지고 있어 환자에게 맞는 치료법을 선택하 는 것이 중요하다. 이 중 경구강 레이저 수술은 방사선 치료 및 개방적 후두 부분 절제술에 비해서 치료 기간이 짧고 비 용이 적게 들며 합병증 및 후유증이 적고 재발 시에도 방사 선을 포함한 다양한 치료 선택을 활용할 수 있다는 점에서 최근 선호되고 있다.,4)

이에 본 저자들은 현재까지 국내외의 연구를 통하여 확보 된 조기 및 일부 진행된 성문암의 치료 방법을 바탕으로, 본 원에서 시행한 조기 및 일부 진행된 성문암에서의 경구강 레 이저 수술의 국소 조절율 및 전체 생존율의 결과를 비교 분 석하며, 나아가 국소 재발에 대한 예측 인자를 알아보고자 하였다.

\section{대상 및 방법}

2008년 1월 2019년 9월까지 본원에서 성문암으로 진단되 어 경구강 레이저 수술을 시행 받은 67명을 대상으로 후향적 연구를 하였다. 이전에 방사선 치료 혹은 경구강 레이저 수술 을 받았던 환자들은 제외하였다. 67명 중 남자가 66명(98.5\%), 여자가 1명(1.5\%)이었고, 연령분포는 45 87세까지로 평균 연
령은 64.3세였다(Table 1). 평균 추적 관찰 기간은 58개월 (9 189개월)이었다. 모든 환자는 갑상연골의 미란이 없고 피 열연골의 움직임에 장애가 없는 환자들을 대상으로 하였다. 경구강 레이저 수술 후 조직 병리 검사를 기준으로 미국 암 학회(American Joint Committee, AJCC)의 TNM 체계에 따 라 분류하였으며 환자의 분포는 pT1 35예(52.2\%), pT2 15예 (22.3\%), pT3 17예(25.3\%)였으며, 모든 증례에서 임상적 경부 림프절 전이와 원격 전이는 없었다.

수술 방법은 레이저 튜브로 기관 삽관을 하여 전신 마취 후 현수 후두경을 삽입하여 수술 시야를 확보하였으며, $400 \mathrm{~mm}$ 렌즈를 가진 수술용 현미경(OPMI Pentero 900; Carl Zeiss, Oberkochen, Germany)에 micromanipulator를 부착한 후 $\mathrm{CO} 2$ 레이저와 연결하여 spot size $0.2 \sim 0.3 \mathrm{~mm}, 3$ watt의 continuous superpulse mode로 병변을 절제하였다. 최대한 정상 성대 조직을 보존하면서 2 3 mm의 자유연을 확보하였 으며, 종양의 크기가 작은 경우에는 일괄절제(en block resection)를 시행하였고, 종양의 크기가 크거나 전교련부 침범이 있는 경우는 여러 조각으로 나누어 절제(blockwise resection) 하였다. 수술 후 처음 1 개월 동안은 2주에 한번, 다음 6 개월 동안은 2 개월에 한번, 그리고 그 이후부터는 환자의 상태 및 증상에 따라 3 6개월마다 한번씩 외래를 방문하도록 하였고, 정기적인 후두내시경 검사와 필요 시 조직 검사를 하여 재발 여부를 확인하였다.

통계분석은 SPSS(IBM ver 24.0; IBM Corp., Armonk, $\mathrm{NY}, \mathrm{USA}$ )을 사용하였다. 경구강 레이저 수술의 5년 국소 조 절율과 생존율은 Kaplan-Meier method를 이용하여 분석하 였고 국소 재발에 대한 단인자 변수는 Fisher's exact test, 다

\begin{tabular}{lc}
$\begin{array}{l}\text { Table 1. Patient and tumor characteristics before transoral laser } \\
\text { microsurgery in } 67 \text { patients with glotticcancer }\end{array}$ \\
\hline \multicolumn{1}{c}{ Characteristics } & No. of patients (\%) \\
\hline All & $67(100)$ \\
Age, y & $64.3(45-87)$ \\
Median (range) & \\
Sex & $66(98.5)$ \\
Male & $1(1.5)$ \\
Female & \\
Smoking & $52(77.6)$ \\
Yes & $15(22.4)$ \\
No & \\
Clinical N classification & $67(100)$ \\
No & 0 \\
N+ & \\
Motility of vocal movement & \\
Impairment & $46(68.7)$ \\
Normal &
\end{tabular}


인자 변수는 Cox proportional-hazards model를 이용하여 분석하였으며 $p$ 값이 0.05 이하인 경우를 통계적으로 유의한 것으로 판정하였다.

본 연구는 성균관대학교 의과대학 강북삼성병원 기관심의 위원회의 심의 및 승인을 받았다(IRB No 2020-09-014).

\section{결 과}

본 연구에서 시행한 경구강 레이저 수술을 European Laryngological Society의 endoscopic cordectomy classification에 따라 분류하면, 전체 67예 중 subepithelial cordectomy (type I)가 2예(3.0\%), subligamental cordectomy(type II)가 15예(22.3\%), transmuscular cordectomy(type III)가 34예 (50.7\%), total or complete cordectomy(type IV)가 4예(5.9\%), extended cordectomy(type V)가 12예(17.9\%)였다(Table 2). 모든 수술 환자에서 수술 당일이나 1 일째 구강 섭식이 가능 하였고 비위관 삽입이 필요할 정도의 흡인이 발생한 환자는 없었으며, 수술 중이나 수술 후 호흡 곤란이 있어 기관 삽관

Table 2. Tumor characteristics and pathologic result after transoral laser microsurgery in 67 patients with glotticcancer

\begin{tabular}{lc}
\hline \multicolumn{1}{c}{ Characteristics } & No. of patients (\%) \\
\hline All & \\
Pathologic T classification & $35(52.2)$ \\
T1 & $15(22.3)$ \\
T2 & $17(25.3)$ \\
T3 & \\
Type of cordectomy & $2(3.0)$ \\
I & $15(22.3)$ \\
II & $34(50.7)$ \\
III & $4(5.9)$ \\
IV & $12(17.9)$ \\
V & \\
Anterior commissure invasion & $21(31.3)$ \\
Yes & $46(68.7)$ \\
No & \\
Difficult laryngeal exposure & $3(4.4)$ \\
Yes & $64(95.6)$ \\
No & \\
Lymphovascular invasion & $8(12.6)$ \\
Yes & $59(87.4)$ \\
No & \\
Margin positive & $17(25.4)$ \\
Yes & $50(74.6)$ \\
No & \\
Yestsurgery radiotherapy & $13(80.6)$ \\
No & \\
\hline
\end{tabular}

이나 기관 절개술이 필요한 경우는 없었다.

수술 6개월 이후 후두내시경 및 $\mathrm{CT}$ 검사상 악성 종양이 발견되었다면 국소 재발이라 정의하였고, 수술 후 조직 검사 결과에서 절제연의 종양 침범이 있으며 6개월 이내에 악성 종 양이 발견되었다면 잔존암으로 분류하였다. 치료 성적을 보면 전체 67예 중 국소 재발이 7예에서 있었으며, T1에서 2예, T2 에서 1예, T3에서 4예였다(Table 3). 재발한 시점은 수술 후 10 60개월 뒤에 확인되었고 평균 40개월이었다. 재발한 7예 중 6예는 초치료로 경구강 레이저 수술만 단독으로 시행 받 았고, 1 예는 초치료로 경구강 레이저 수술 후 방사선 치료를 병행하였다. 재발한 1 예에서는 구제 치료로 방사선 치료를, 4예에서는 다시 경구강 레이저 수술을 시행하였다. 전체 5년 국소 조절률은 $81.9 \%$ 로, 조기 성문암(T1, T2)에서는 $87.8 \%$, 일부 진행된 성문암(T3)에서는 $63.5 \%$ 를 보였다(Table 4 , Fig. 1). 전체 5년 생존률은 $93.3 \%$ 로, 조기 성문암(T1, T2)에 서는 $96.1 \%$, 일부 진행된 성문암(T3)에서는 $87.5 \%$ 를 보였다. 사망한 4예에서는 췌장암 및 기흥 등이 사망원인이었고, 성 문암이 직접적인 사인이 된 경우는 없었다.

수술 후 국소 재발에 영향을 미치는 인자를 확인하기 위하 여 수술 전 T stage, 성대 운동의 장애(vocal cord movement impairment), 전교련부 침범(anterior commissure invasion), 림프혈관 침범(lymphovascular invasion), 절제연의 종양 침 범(margin positive), 수술 중 시야 확보가 어려운 경우(difficult laryngeal exposure), 수술 후 방사선 치료(postsurgery radiotherapy) 각각에 대하여 통계적 유의성을 분석하였다. 이 중 전교련부 침범, 림프혈관 침범, 절제연의 종양 침범, 수 술 중 시야 확보가 어려운 경우가 수술 후 국소 재발과 통계 적으로 유의한 연관성이 있음을 확인하였다(Table 5). 이들과 연관된 인자 중 국소 재발에 영향을 미치는 다인자 변수를 분석한 결과, 전교련부 침범과 림프혈관 침범이 통계적으로 유의한 연관성이 있었다(Table 6).

\section{고 찰}

성문암은 애성 등의 증상이 초기에 나타나 조기 발견이 용 이하고, 림프관의 발달이 거의 없어 림프 전이나 원격 전이가 적어 다른 두경부암에 비해 좋은 예후를 보이는 것으로 알려 져 있다. AJCC의 분류상 국소 및 원격 전이가 없는 Tis, T1, $\mathrm{T} 2$ 를 조기 성문암으로 분류한다. 조기 성문암은 근육이나 연 골은 침범하지 않으며 병리조직학적으로 미세 침윤만이 있는 상태로 성대의 운동성에 제한이 없어야 하며, 이런 조기 성 문암의 치료로 방사선 치료와 경구강 레이저 수술, 개방적 후두 보존 절제술이 있으며 방법 간의 치료 성적율은 비슷한 


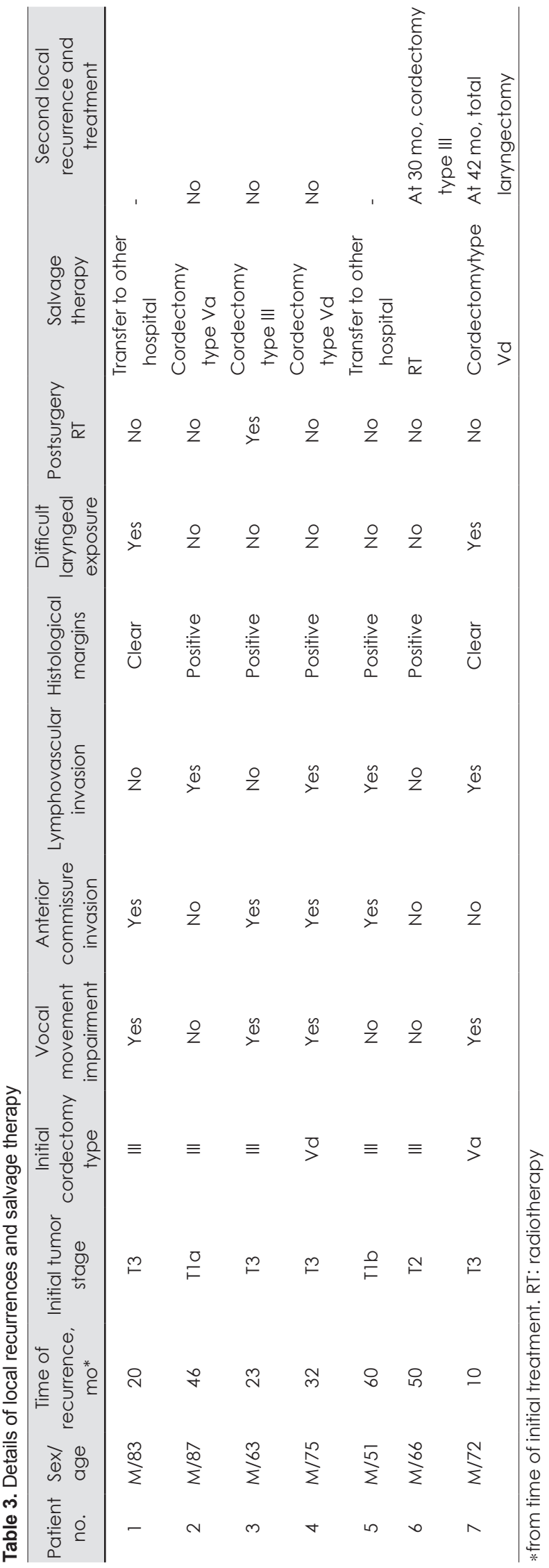

Table 4. Oncologic results of patients with glotticcancer after Transoral laser microsurgery

\begin{tabular}{lc}
\hline \multicolumn{1}{c}{ Outcomes } & No. of patients/total (\%) \\
\hline Local recurrence & \\
Yes & $7 / 67(10.4)$ \\
No & $60 / 67(89.6)$ \\
5-year local control rate & $7 / 67(81.9)$ \\
Early stage (T1, T2) & $3 / 50(87.8)$ \\
Advanced stage (T3) & $4 / 17(63.5)$ \\
5-year overall survival rate & $4 / 67(93.3)$ \\
Early stage (T1, T2) & $2 / 50(96.1)$ \\
Advanced stage (T3) & $2 / 17(87.5)$ \\
\hline
\end{tabular}

것으로 알려져 있다. ${ }^{3)}$

경구강 레이저 성대 절제술은 1972년 Strong과 Jako가가 처 음 소개하였고 이후 한 연구에 발표된 조기 성문암에서의 경 구강 수술의 국소 조절율은 $94 \%$ 를 보였다. ${ }^{5)}$ 다른 연구에서는 $\mathrm{T} 1$ 환자군에서 $87 \%, \mathrm{~T} 2$ 환자군에서 $84.6 \%$ 의 국소 조절율을 보고하였으며, ${ }^{6}$ 이 같은 여러 연구들이 조기 성문암에서 80 95\% 이상의 치료 성적을 보이면서 경구강 레이저 수술이 방 사선 치료와 함께 조기 성문암에서 최우선 치료(treatment of choice)로 여겨지고 있다. ${ }^{5-7)}$ 본 연구의 결과에서는 조기 성문 암에서 $87.8 \%$ 의 5 년 국소 조절율과 $96.1 \%$ 의 5년 전체 생존 율을 보였다.

나아가 최근에는 진행된 성문암에서도 경구강 레이저 수술 을 시행한 많은 연구가 보고되고 있다. 한 연구에서는 T3 환 자군에서 $47.1 \%$ 의 국소 조절율, $73.1 \%$ 의 5년 전체 생존율을 보고하였다. ${ }^{8}$ 또한, $\mathrm{T} 4 \mathrm{a}$ 환자군에서는 경구강 레이저 수술과 함께 (항암)방사선 치료를 시행하였을 때 $66.6 \%$ 의 5년 국소 조절율을 나타내기도 하였다. ${ }^{9}$ 본 연구의 결과에서는 진행된 성문암 환자들 중 성문주위 공간의 침범이 있으나, 갑상연골 의 미란이 없고 피열 연골의 움직임에 장애가 없는 환자들에 게 경구강 레이저 수술을 시행하였고 $63.5 \%$ 의 5년 국소 조절 율 및 $87.5 \%$ 의 5년 전체 생존율을 보였다.

이전 연구에서 $\mathrm{T} 3$ 환자에서 초치료로 항암방사선 치료를 시행한 경우 30 68\%의 5년 국소 조절율 및 51 59\%의 5년 전체 생존율이 보고되었다. ${ }^{1-14)}$ 다른 메타분석에서는 $\mathrm{T} 3$ 성문 암 환자에서 후두전절제술과 경구강 레이저 수술의 5 년 국소 조절율은 각각 $77.3 \%, 64.3 \%$ 을 보였고, 5년 전체 생존율은 $55.7 \%, 60.2 \%$ 을 보였다. 종합하면 T3 환자에서 경구강 레이 저 수술, 항암방사선 치료, 단독 방사선 치료 각각의 전체 생 존율 및 질병특이 생존율에는 큰 차이를 보이지 않았지만 국 소 조절율은 방사선 치료를 단독으로 하는 경우에는 다소 낮게 보고되었다. ${ }^{15)}$ 아직까지 진행된 성문암에서의 경구강 레 이저 수술의 적용은 논란의 여지가 있지만, 이러한 이전 연구 

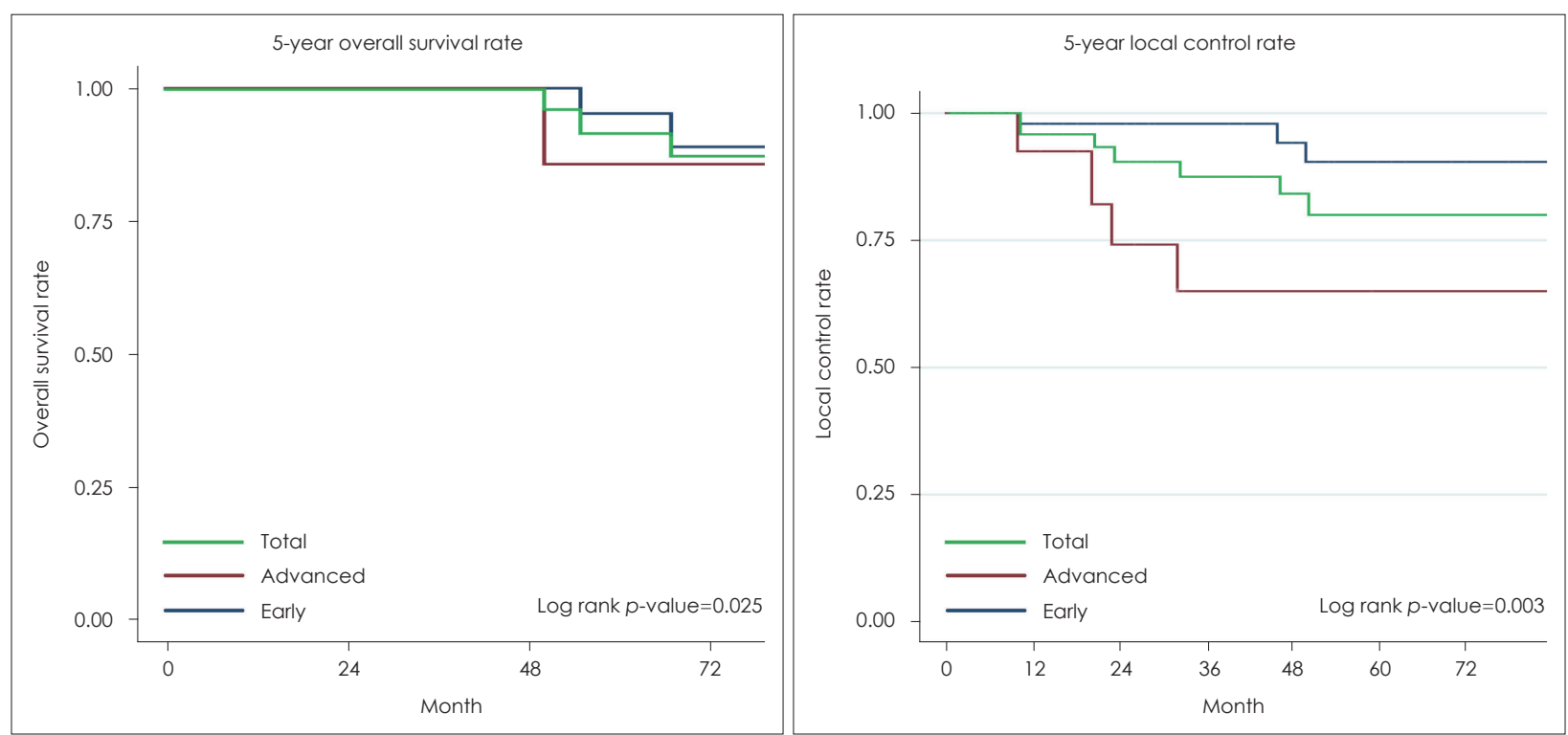

Fig. 1. Comparison of 5-year overall survival rate and local control rate between early and advanced glottis cancer.

Table 5. Univariate analysis with fisher's exact test for predictors of local recurrence of glotticcancer

\begin{tabular}{|c|c|c|c|}
\hline Factors & $\begin{array}{c}\text { No. of } \\
\text { patients (\%) }\end{array}$ & $\begin{array}{l}\text { Odd ratio } \\
(95 \% \mathrm{Cl})\end{array}$ & $p$-value \\
\hline \multicolumn{3}{|l|}{ Primary T stage } & 0.07 \\
\hline Advanced stage (T3) & $17(25.4)$ & $4.6(0.9-23.3)$ & \\
\hline Early stage $(\mathrm{T} 1, \mathrm{~T} 2)$ & $50(74.6)$ & 1 (reference) & \\
\hline \multicolumn{3}{|c|}{ Vocal movement impairment } & 0.189 \\
\hline Yes & $21(31.3)$ & $3.5(0.7-17.4)$ & \\
\hline No & $46(68.7)$ & 1 (reference) & \\
\hline \multicolumn{3}{|c|}{ Anterior commissure invasion } & 0.004 \\
\hline Yes & $21(31.3)$ & $17.2(1.9-154.7)$ & \\
\hline No & $46(68.7)$ & 1 (reference) & \\
\hline \multicolumn{3}{|c|}{ Lymphovascular invasion } & 0.003 \\
\hline Yes & $8(12.6)$ & $18.0(2.9-109.8)$ & \\
\hline No & $59(87.4)$ & 1 (reference) & \\
\hline \multicolumn{3}{|l|}{ Margin positive } & 0.011 \\
\hline Yes & $17(25.4)$ & $9.5(1.6-55.6)$ & \\
\hline No & $50(74.6)$ & 1 (reference) & \\
\hline \multicolumn{3}{|c|}{ Difficult laryngeal exposure } & 0.03 \\
\hline Yes & $3(4.4)$ & $22.8(1.7-297.4)$ & \\
\hline No & $64(95.6)$ & 1 (reference) & \\
\hline \multicolumn{3}{|c|}{ Postsurgery radiotherapy } & 1.00 \\
\hline Yes & $13(19.4)$ & $0.64(0.7-5.8)$ & \\
\hline No & $54(80.6)$ & 1 (reference) & \\
\hline
\end{tabular}

Cl: confidence interval

결과들은 진행된 성문암에서도 초치료로 경구강 레이저 수 술을 시행할 수 있는 근거를 뒷받침하고 있다. 본 연구에서 일부 진행된 T3 성문암 환자에게 시행한 경구강 레이저 수술 의 치료 결과 역시 이전 연구에서 보여진 항암방사선 치료, 후두전절제술의 결과와 비슷한 국소 조절율 및 생존율을 보
Table 6. Multivariate analysis with Cox proportional-hazards model for predictors of local recurrence of glottic cancer

\begin{tabular}{cccc}
\hline Factors & $\begin{array}{c}\text { No. of } \\
\text { patients }(\%)\end{array}$ & $\begin{array}{c}\text { Hazard ratio } \\
(95 \% \mathrm{Cl})\end{array}$ & p-value \\
\hline Vocal movement impairment & & 0.130 \\
Yes & $21(31.3)$ & $6.0(0.59-61.34)$ & \\
No & $46(68.7)$ & 1 (reference) &
\end{tabular}

Anterior commissure invasion

$\begin{array}{lcc}\text { Yes } & 21(31.3) & 18.4(1.98-170.99) \\ \text { No } & 46(68.7) & 1 \text { (reference) }\end{array}$

Lymphovascular invasion

0.015

$\begin{array}{lrc}\text { Yes } & 8(12.6) & 7.5(1.49-38.15) \\ \text { No } & 59(87.4) & 1 \text { (reference) } \\ \text { Margin positive } & & \\ \text { Yes } & 17(25.4) & 3.7(0.54-25.61) \\ \text { No } & 50(74.6) & 1 \text { (reference) }\end{array}$

Postsurgery radiotherapy

$\begin{array}{lrr}\text { Yes } & 13(19.4) & 0.59(0.05-6.00) \\ \text { No } & 54(80.6) & 1 \text { (reference) }\end{array}$

0.660

\section{Cl: confidence interval}

이는 것을 확인할 수 있었다. 따라서, 갑상연골의 미란이 없고 피열연골 움직임에 장애가 없는 T3 성문암 환자에서 초치료 로서 다른 치료법과 마찬가지로 경구강 레이저 수술 역시 좋 은 치료 방법 중 하나로 제시될 수 있는 근거를 확인하였다.

성문암에서의 방사선 치료는 오래전부터 널리 이용되고 있 었고 조기 성문암에서 치료 성적이 우수하며, 다른 치료법에 비해 치료 후 음성의 질이 좋은 장점이 있다. 하지만 5 6주간 의 장기간 치료 기간과 방사선 자체에 의한 부작용과 재발 시 구제 치료의 방법이 제한되며 구제 수술 후 합병증이 발생할 확률이 높다는 단점이 있다.,16,17) 개방적 후두 부분 절제술은 
종양의 범위를 명확히 파악할 수 있다는 장점이 있으나 피부 절개와 기관 절개술이 필요하며 회복기간이 길고 음성의 질 이 떨어지며 술후 흡인의 가능성이 있다. ${ }^{18,19)}$

경구강 레이저 수술은 방사선 치료 및 개방적 후두 부분 절 제술에 비해서 치료 기간이 짧고 비용이 적게 들며 합병증 및 후유증이 적고 재발 시에도 다시 경구강 레이저 수술을 시행 하거나 방사선 치료, 후두 절제술 등의 다양한 치료 선택이 가능하다. ${ }^{20,21)}$ 이전 연구에서 (항암)방사선 치료 후 재발한 성 문암 환자에게 경구강 레이저 수술을 구제 치료로 시행하였 을 때 2년 전체 생존률은 $74.8 \%$, 후두 보존율은 $72.3 \%$ 을 보 였다. ${ }^{22)}$ 다른 연구에서는 16 예의 환자에서 경구강 레이저 수 술을 구제 치료로 시행하였을 때 14 예에서 완치되었고 국소 조절율은 $87.1 \%$ 였다. ${ }^{23)}$ 본원에서는 경구강 레이저 수술을 시 행 받은 성문암 환자에서 7예가 재발하였고, 재발한 4예는 구제 치료로 경구강 레이저 수술을, 1 예에서는 방사선 치료를 시행하였다. 구제 치료로 경구강 레이저 수술을 받은 4예 중 3 예는 재발 없이 경과 관찰 중이며, 방사선 치료를 받은 1 예는 재발하여 경구강 레이저 수술을 받아 현재 재발 소견 없이 경과 관찰 중에 있다.

최근 성문암에서 경구강 레이저 수술 후 국소 재발의 예측 인자들에 관한 연구들이 보고되고 있으며 그 중 하나는 국소 재발과 관련 있는 변수로 연령, 절제연의 종양 침범, 성대절제 술의 유형과 T stage만이 유의미하다고 하였으며, ${ }^{24}$ 성대 운 동성의 장애와 국소 연골 침윤만이 유의미하다고 보고한 연 구도 있다. ${ }^{8}$ 전교련부는 해부학적인 장벽이 없고, 현수 후두 경하에 수술 시 시야 확보가 어려워 전교련부를 침범한 경우 $40 \%$ 만이 완전 절제가 가능하며 종양의 불충분한 절제로 인 해 국소 재발이 높다고 하였다. ${ }^{25,26)}$ 하지만 다른 연구에서 수 술 중 시야 확보가 수월하다면 전교련부 침범이 있어도 국소 재발율에 유의미한 차이가 없는 결과를 보여 ${ }^{27)}$ 전교련부 자체 의 침범보다는 침범된 부위의 시야 확보가 중요할 것이라고 생각된다. 수술 시 환자의 해부학적 특성을 고려하여 시야 확 보가 아주 어렵다고 판단되는 경우는 방사선 치료를 먼저 고 려할 수 있으나 각각의 장단점이 있어 환자에 따라 다양한 치 료 방법을 고려해야 한다. 본 연구에서는 수술 시 외부에서 목을 눌러주거나 다양한 후두경을 사용하여 대부분의 환자 에서 적절한 시야 확보가 가능하였다. 하지만, 시야 확보가 어 려운 환자에서 재발율이 높은 결과를 확인할 수 있어서 절제 연을 충분히 얻지 못했다면 재발을 막기 위해 수술 후 방사선 치료를 고려해야 할 것으로 생각된다.

절제연에서 종양 침범이 있는 경우 51.3 81.9\%, 종양 침범 이 없는 경우 78.4 95\%의 국소 조절율이 보고되고 있으며, ${ }^{28)}$ 절제연에서 종양 침범이 있다면 이후의 치료는 술자의 의견
이 가장 중요하다. 일반적으로 경구강 레이저 수술을 다시 시행하거나, 방사선 치료 혹은 조심스럽게 경과 관찰을 해 볼 수 있다. 보통 경구강 레이저 수술은 수술 후 2주 6달 후에 다시 시행하며, 수술 후 방사선 치료는 2 군데 이상의 절제연 에서의 침범이 관찰되거나, 성문 주위 공간(paraglottic space) 의 침범이 있는 경우 시행할 수 있다. ${ }^{29,30)}$ 본 연구에서는 성문 암에서 경구강 레이저 수술을 받은 환자들에게 전교련부 침 범, 림프혈관 침범이 국소 재발의 유무와 통계적으로 유의미 한 연관성이 있음을 확인하였다.

수술 후 방사선 치료의 결정은 수술 시 절제연 확보 여부가 중요하며 본 연구에서는 성문주위 공간에 침범이 있는 진행 된 성문암 환자에서 절제연 종양 침범이 있는 경우에 방사선 치료를 추가하였고, 조기 성문암에서는 대부분 방사선 치료 를 추가하지 않고 정기적인 경과 관찰 및 추적 검사를 시행하 였다. 따라서, 본 연구의 제한점으로 경구강 레이저 수술 후 방사선 치료를 받은 환자가 대상군에 포함되어 있어, 방사선 치료의 영향을 정확하게 판단하기 어려운 점이 있다. 하지만, 수술 후 방사선 치료를 받은 13 명을 제외하더라도 경구강 레 이저 수술의 5 년 국소 조절율이 조기 성문암 환자 42 명은 $88.7 \%$, 진행된 성문함 환자 12 명은 $60 \%$ 을 보였다. 본 연구에 포함된 환자 수가 비교적 적었기 때문에 추후 보다 많은 환 자를 대상으로 방사선 치료를 포함한 연구가 필요하다고 생 각된다.

결론적으로, 본 연구에서는 이전 발표된 연구들과 비슷하 게 경구강 레이저 수술이 조기 성문암 환자에게 높은 국소 조 절율 및 생존율을 보인 것을 확인하였다. 갑상연골의 미란이 없고 피열연골의 움직임에 장애가 없는 진행된 성문암에서 경구강 레이저 수술의 치료 결과는 조기 성문암에 비해 생존 율과 국소 조절율은 조금 낮지만, 일반적인 항암방사선 치료 나 고식적 수술과 비교하면 비슷한 국소 조절율과 생존율을 보였다. 또한, 전교련부 침범, 림프혈관 침범이 국소 재발과 유 의미한 연관성이 있음을 확인하였고, 이를 통해 경구강 레이 저 수술 후 국소 재발의 조기 발견 및 치료에 도움이 될 것이 라고 생각한다.

\section{Acknowledgments}

None.

\section{Author Contribution}

Conceptualization: Sang Hyuk Lee. Data curation: Sang Hyuk Lee, Sun Woo Kim. Formal analysis: Sang Hyuk Lee, Sun Woo Kim, Hye Soo Kim. Methodology: Sun Woo Kim, Woo Joo Nam. Writing - original draft: Sun Woo Kim. Writing - review \& editing: Sang Hyuk Lee, Sung Min Jin, Sun Woo Kim. 


\section{ORCID}

Sang Hyuk Lee https://orcid.org/0000-0003-4412-3486

\section{REFERENCES}

1) Montgomery WW. Salivary bypass tube. Ann Otol Rhinol Laryngol 1978;87(2 Pt 1):159-62.

2) Strong MS, Jako GJ. Laser surgery in the larynx. Early clinical experience with continuous CO 2 laser. Ann Otol Rhinol Laryngol 1972;81(6):791-8.

3) Park JH, Paeng JP, Na HS, Lim KJ, Kwon SY, Jung KY, et al. Treatment results of laser cordectomy and radiation therapy for early glottic cancer. Korean J Otolaryngol 2002;45(2):159-63.

4) Tae K, Ji YB, Jin BJ, Park CW, Lee HS. Transoral $\mathrm{CO}_{2}$ laser cordectomy in early glottic cancer. Korean J Otolaryngol 2006; 49(5):538-42.

5) Steiner W. Results of curative laser microsurgery of laryngeal carcinomas. Am J Otolaryngol 1993;14(2):116-21.

6) Eckel HE. Local recurrences following transoral laser surgery for early glottic carcinoma: Frequency, management, and outcome. Ann Otol Rhinol Laryngol 2001;110(1):7-15.

7) Rudert HH, Werner JA. Endoscopic resections of glottic and supraglottic carcinomas with the CO2 laser. Eur Arch Otorhinolaryngol 1995;252(3):146-8.

8) Vilaseca I, Bernal-Sprekelsen M, Luis Blanch J. Transoral laser microsurgery for T3 laryngeal tumors: Prognostic factors. Head Neck 2010;32(7):929-38.

9) Canis M, Ihler F, Martin A, Wolff HA, Matthias C, Steiner W. Results of 226 patients with $\mathrm{T} 3$ laryngeal carcinoma after treatment with transoral laser microsurgery. Head Neck 2014;36(5):652-9.

10) Harwood AR, Beale FA, Cummings BJ, Hawkins NV, Keane TJ, Rider WD. T3 glottic cancer: An analysis of dose time-volume factors. Int J Radiat Oncol Biol Phys 1980;6(6):675-80.

11) Jørgensen K, Godballe C, Hansen O, Bastholt L. Cancer of the larynx--treatment results after primary radiotherapy with salvage surgery in a series of 1005 patients. Acta Oncol 2002;41(1):69-76.

12) Parsons JT, Mendenhall WM, Mancuso AA, Cassisi NJ, Stringer SP, Million RR. Twice-a-day radiotherapy for T3 squamous cell carcinoma of the glottic larynx. Head Neck 1989;11(2):123-8.

13) Wylie JP, Sen M, Swindell R, Sykes AJ, Farrington WT, Slevin NJ. Definitive radiotherapy for 114 cases of T3N0 glottic carcinoma: Influence of dose-volume parameters on outcome. Radiother Oncol 1999;53(1):15-21.

14) Fu X, Zhou Q, Zhang X. Efficacy comparison between total laryngectomy and nonsurgical organ-preservation modalities in treatment of advanced stage laryngeal cancer: A meta-analysis. Medicine (Baltimore) 2016;95(14):e3142.

15) Kim BH, Park SJ, Jeong WJ, Ahn SH. Comparison of treatment outcomes for T3 glottic squamous cell carcinoma: A meta-analysis. Clin Exp Otorhinolaryngol 2018;11(1):1-8.

16) Chung PS, Lee SJ, Kim YH, Park SJ, Yoon JS. Comparison of radiotherapy with laser cordectomy for $\mathrm{T} 1$ glottic cancer. Korean $\mathrm{J}$
Otolaryngol 2005;48(9):1161-5.

17) Cragle SP, Brandenburg JH. Laser cordectomy or radiotherapy: Cure rates, communication, and cost. Otolaryngol Head Neck Surg 1993;108(6):648-54.

18) de Campora E, Radici M, de Campora L. External versus endoscopic approach in the surgical treatment of glottic cancer. Eur Arch Otorhinolaryngol 2001;258(10):533-6.

19) Thomas JV, Olsen KD, Neel HB 3rd, DeSanto LW, Suman VJ. Early glottic carcinoma treated with open laryngeal procedures. Arch Otolaryngol Head Neck Surg 1994;120(3):264-8.

20) Casiano RR, Cooper JD, Lundy DS, Chandler JR. Laser cordectomy for T1 glottic carcinoma: A 10-year experience and videostroboscopic findings. Otolaryngol Head Neck Surg 1991;104(6):831-7.

21) Gallo A, de Vincentiis M, Manciocco V, Simonelli M, Fiorella ML, Shah JP. CO2 laser cordectomy for early-stage glottic carcinoma: A long-term follow-up of 156 cases. Laryngoscope 2002;112(2): 370-4.

22) Ramakrishnan Y, Drinnan M, Kwong FN, Grant DG, Mehanna H, Jones T, et al. Oncologic outcomes of transoral laser microsurgery for radiorecurrent laryngeal carcinoma: A systematic review and meta-analysis of English-language literature. Head Neck 2014; 36(2):280-5.

23) Puxeddu R, Piazza C, Mensi MC, Ledda GP, Argiolas F, Peretti G. Carbon dioxide laser salvage surgery after radiotherapy failure in T1 and T2 glottic carcinoma. Otolaryngol Head Neck Surg 2004; 130(1):84-8.

24) Ansarin M, Cattaneo A, De Benedetto L, Zorzi S, Lombardi F, Alterio D, et al. Retrospective analysis of factors influencing oncologic outcome in 590 patients with early-intermediate glottic cancer treated by transoral laser microsurgery. Head Neck 2017; 39(1):71-81.

25) Thomas JV, Olsen KD, Neel HB 3rd, DeSanto LW, Suman VJ. Recurrences after endoscopic management of early (T1) glottic carcinoma. Laryngoscope 1994;104(9):1099-104.

26) Wolfensberger M, Dort JC. Endoscopic laser surgery for early glottic carcinoma: A clinical and experimental study. Laryngoscope 1990;100(10 Pt 1):1100-5.

27) Chang CF, Chu PY. Predictors of local recurrence of glottic cancer in patients after transoral laser microsurgery. J Chin Med Assoc 2017;80(7):452-7.

28) Peretti G, Piazza C, Cocco D, De Benedetto L, Del Bon F, Redaelli De Zinis LO, et al. Transoral CO(2) laser treatment for T(is)-T(3) glottic cancer: The University of Brescia experience on 595 patients. Head Neck 2010;32(8):977-83.

29) Ansarin M, Santoro L, Cattaneo A, Massaro MA, Calabrese L, Giugliano G, et al. Laser surgery for early glottic cancer: Impact of margin status on local control and organ preservation. Arch Otolaryngol Head Neck Surg 2009;135(4):385-90.

30) Crespo AN, Chone CT, Gripp FM, Spina AL, Altemani A. Role of margin status in recurrence after $\mathrm{CO} 2$ laser endoscopic resection of early glottic cancer. Acta Otolaryngol 2006;126(3):306-10. 